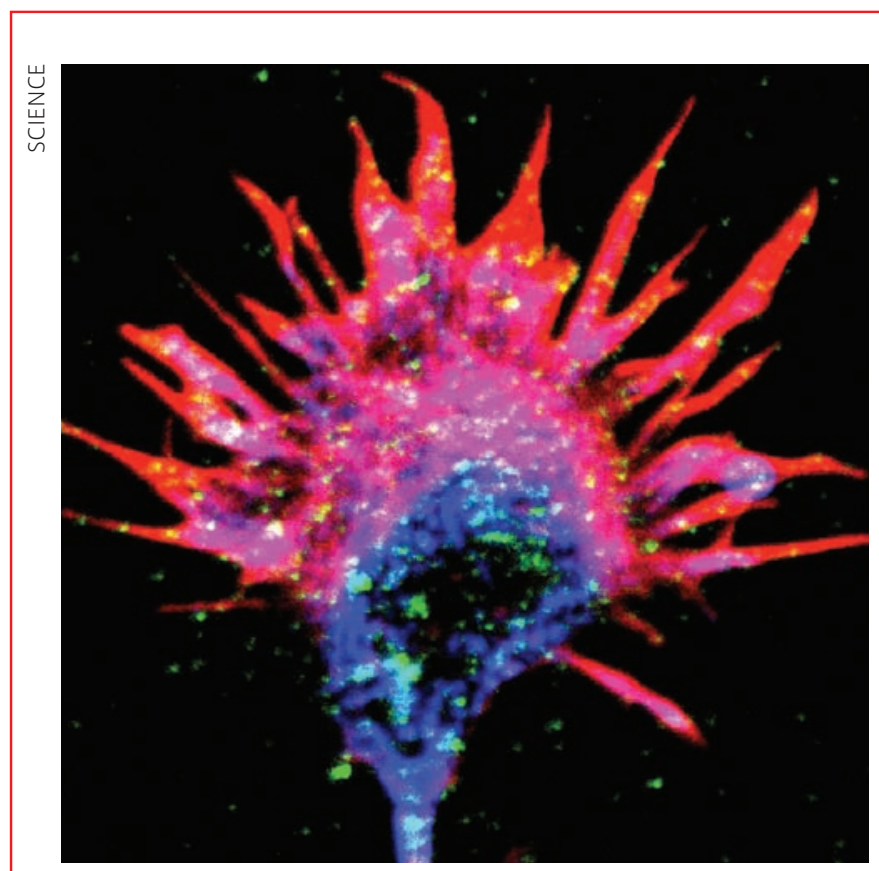

\title{
Trippy tips
}

迷走する先端

Science 316, 1212-1216 (2007)

カンナビノイドはマリファナに含まれる精神活性物質として知られて いることが多いが、脳内で作られる内在性カンナビノイドは、これと は別の役割を担っている。最近の研究は、これらが発生中の神経線維 の誘導に関与している可能性を示唆している。

カロリンスカ研究所 (スウェーデン、ストックホルム) のTibor Harkany率いる研究チームは、細胞培養中の二ューロンのカンナビ ノイド受容体 $C_{1} \mathrm{R}$ (左写真)の動きを追跡した。彼らは、神経線維(青) の成長中の先端（ピンク色）にCB1R (緑色) が集まっていることを 発見した。活性化した CB1Rは神経線維の伸長を抑制し、カンナビノ イドのシグナルの方向を避けるように神経線維を成長させた。

生きたマウスのある種の二ューロンから CB1R を除去すると、軸索 間の連結パターンが変化した。著者らは、妊娠中の女性がマリファ ナを使用すると、胎児のカンナビノイドシグナル伝達と干渉を起こし、 ニューロンの発生に悪影響を及ぼすのではないかと推測している。

\section{Cloudy skies ahead}

雲行きを見る

Geophys. Res. Lett. 34, L09811 (2007)

NASAのクラウドサット (右図) 衛星の初期データは、地球表面の雲 の分布や大気中の雲の垂直構造を詳細に解明する役に立つ。こうした 情報は正確な全地球気候モデルを構築するうえで重要である。

コロラド州立大学（フォートコリンズ）のJohn Haynes と Graeme Stephens の報告によると、2006年4月に衛星が打ち上げられてから 最初の3か月間に収集されたデータから、熱帯の海洋の上空にある雲 が大きく2種類に分類できることがわかった。1つは雲頂高度が約 2 キ ロメートルの雲であり、もう $1 つ は 12$ キロメートル前後に達する雲で ある。さらに、西太平洋の上空では、この中間の高さに雲の層がある ことが多いこともわかった。衛星が検出した雲の18パーセントは雨雲 であり、雨を作らない雲に比べて著しく厚かった。
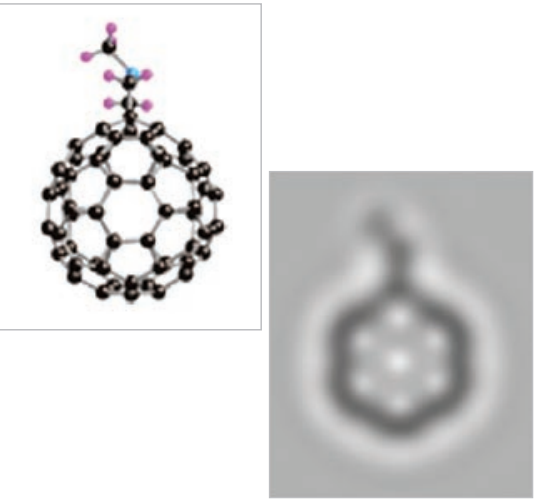

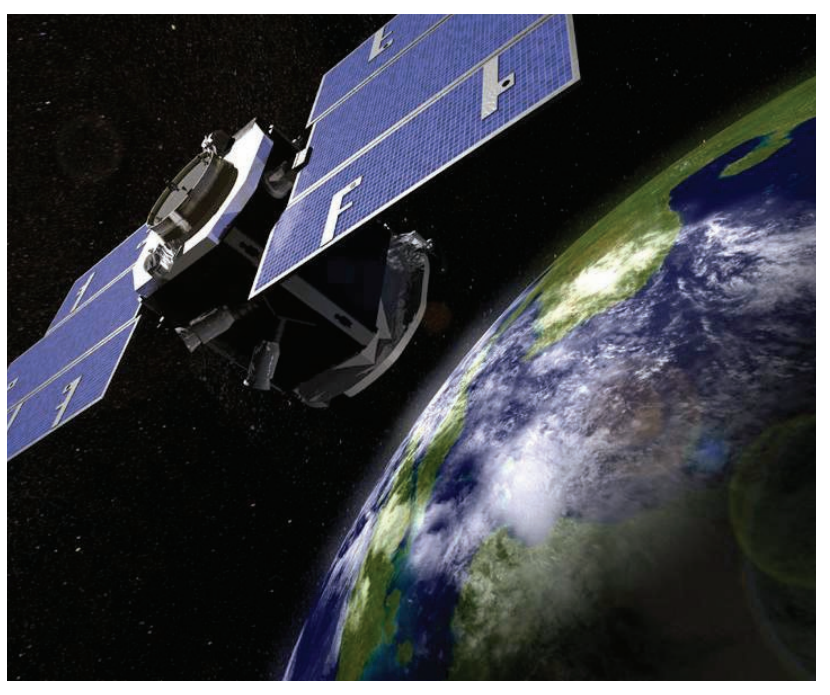

\section{Spot the ball}

ボールの模様を突き止める

J.Am.Chem.Soc.129,6666-6667(2007).

サッカーボールの形をしたC 60 分子の高度に対称的な原子構造が、電子 顕微鏡を使って初めて観察された。

産業技術総合研究所（つくば市）の末永和知らは、カーボンナノ チューブの表面に係留した $C_{60}$ 分子の個々の姿を撮影することに成功 した。これらの画像 (例:左写真) を、分子の二十面体のかご構造 (中 図）に基づく画像シミュレーション（右図）と比較することで、観察 された二次元の形態を炭素シェルのさまざまな投影図に対応させるこ とができる。これらは五角形と六角形の輪からできている。

研究者らはまた、ゆがんだ非球形のシェルもいくつか観察すること ができた。彼らはこれを、電子線によりC2 ユニットがシェルからは じき出されて生じたC 58 分子であると考えている。 